\title{
Pengaruh Varietas dan Paket Pemupukan pada Fase Produktif terhadap Kualitas Melon (Cucumis melo L.) di Quartzipsamments
}

\author{
The Effect of Varieties and On-productive-stage Fertilization Packages toward the \\ Quality of Melon (ucumis $\underline{\text { melo L.) in Quartzipsamments }}$
}

Muhammad Anang Firmansyah ${ }^{1 *}$, Wahyu Adi Nugroho' ${ }^{1}$, dan Suparman ${ }^{1}$

Diterima 23 Januari 2018/Disetujui 06 Mei 2018

\begin{abstract}
Melon (Cucumis $\underline{\text { melo }}$ L.), one of the high-value fruits, has been started to expand by farmers but the heterogeneity in quality may constrain the development. This study aimed to improve the quality of melon in quartz-sand soil (Quartzipsamments). A field experiment based on the split-plot design was conducted on April to June 2016 in Kotawaringin Timur Regency, Central Kalimantan Province, using two factors comprising melon varieties and on-productive-stage fertilization. The varieties consist of Rio F1 (V1), Action 434 F1 (V2), Madesta F1 (V3), Dewo F1 (V4), Gracia F1 (V5), and Okasa F1 (V6). While four fertilization packages which have different dosage on each were tested, including control (P0), low (P2), medium (P3), and high (P3). The result indicated that either varieties or fertilizing significantly affected growth, yield, and the quality of melon. There was a significant interaction between varieties and fertilizing toward yield and quality. Madesta F1 is the only varieties which showed positive response along with increasing fertilizer dosage, and the highest weight 4.55 $\mathrm{kg}$ ) occurred on the high fertilizing level (P3). While in regard to sweetness level, Rio F1 showed a positive response until medium fertilizing dosage (P2) and resulted in the highest sweetness level by $13.05^{\circ}$ Brix but decreased on the higher dosage (P3). The fruit weight slightly-negative correlated with total sweetness level where the increase in weight may reduce the sweetness level.
\end{abstract}

Keywords: lowland, quartz sand, sweetness level

\begin{abstract}
ABSTRAK
Melon (Cucumis melo L.) sebagai salah satu komoditas bernilai ekonomis tinggi mulai dikembangkan banyak petani, namun terkendala dengan kualitas buah yang beragam. Penelitian ini bertujuan untuk meningkatkan mutu buah melon di tanah pasir kuarsa (Quartzipsamment). Percobaan lapangan dengan Rancangan Petak Terbagi dilakukan pada bulan April hingga Juni 2016 di Kabupaten Kotawaringin Timur, Provinsi Kalimantan Tengah, dengan menggunakan dua faktor, yaitu varietas dan dosis pemupukan pada fase produktif. Faktor varietas terdiri atas: Rio F1 (V1), Action 434 F1 (V2), Madesta F1 (V3), Dewo F1 (V4), Gracia F1 (V5), dan Okasa F1 (V6). Sedangkan faktor pemupukan pada fase produktif terdiri atas: kontrol (P0), rendah (P2), sedang (P3), dan tinggi (P3). Hasil penelitian menunjukkan bahwa faktor varietas maupun pemupukan berpengaruh terhadap peubah pertumbuhan, hasil, maupun kualitas. Terdapat interaksi yang nyata antara varietas dan pemupukan terhadap peubah hasil maupun kualitas buah. Madesta F1 adalah satu-satunya varietas yang menunjukkan respon positif dengan meningkatnya dosis pemupukan, dengan bobot buah tertinggi sebesar $4.55 \mathrm{~kg}$ dicapai pada perlakuan dosis tinggi (P3). Untuk kemanisan buah, varietas Rio F1 menunjukan respon positif dengan adanya peningkatan dosis hingga dosis sedang (P2) dengan nilai kemanisan tertinggi di antara yang lain (13.05 ${ }^{\circ}$ Brix $)$, namun menurun pada dosis yang lebih tinggi (P3). Bobot buah berkorelasi negatif yang tidak terlalu erat dengan tingkat kemanisan total buah, semakin tinggi bobot cenderung menurunkan tingkat kemanisan buah.
\end{abstract}

Kata kunci: dataran rendah, pasir kuarsa, tingkat kemanisan

${ }^{1}$ Balai Pengkajian Teknologi Pertanian Kalimantan Tengah

Jl. G. Obos Km 5 Palangka Raya 73111

Email: anang.firmansyah75@yahoo.com (*Penulis korespondensi) 


\section{PENDAHULUAN}

Melon (Cucumis melo L.) merupakan salah satu komoditas buah-buahan yang banyak mengandung manfaat. Kandungan di berbagai bagian buah melon antara lain beta karoten, apokarotenoid, asam askorbat, flavonoid, terpenoid, derivad kromone, karbohidrat, asam amino, asam lemak, fosfolipid, glikolipid, komponen volatil, dan berbagai mineral (Milind dan Kulwant, 2011).

Tanaman melon yang ditanam di tanah marjinal, umumnya terkendala oleh kualitas buah yang beragam. Satu hal yang dimungkinkan menjadi penyebabnya adalah belum sesuainya pemupukan yang telah diterapkan. Jika pupuk kurang tersedia bagi tanaman, tanaman melon tidak dapat mengalami peningkatan pertumbuhan dan produksi tanaman secara signifikan (Setyawaty dan Wijaya, 2012). Sebaliknya, jika pemupukan mencukupi, maka berpengaruh positif terhadap peningkatan pertumbuhan dan produksi tanaman (Simanungkalit et al., 2013).

Unsur hara makro memiliki peran penting dalam mendukung pertumbuhan dan produksi tanaman melon. Simanungkalit et al. (2013) menyatakan bahwa bahwa pemberian pupuk NPK dan pemangkasan buah berpengaruh nyata terhadap panjang sulur, jumlah daun, produksi tanaman, dan produksi per plot melon varietas Action 434 F1 didataran rendah. Sedangkan konsentrasi unsur hara di dalam buah melon bergantung pada perlakuan budidaya yang dilakukan serta varietas yang digunakan. Rata-rata kandungan $\mathrm{N}, \mathrm{P}, \mathrm{K}, \mathrm{Mg}$, dan $\mathrm{Ca}$ di dalam buah melon bertutut-turut adalah $1.3,0.4,4.3,0.2$, dan 0.4 g. $\mathrm{kg}^{-1}$ bobot kering (Gadomaka, 2009).

Sehubungan dengan peningkatan produksi dan kualitas buah, pemenuhan unsur hara pada fase produktif menjadi sangat penting untuk dilakukan. Hal ini dikarenakan penyerapan beberapa unsur hara penting terutama kalium oleh tanaman meningkat saat penyerbukan hingga awal pembentukan buah (Asao et al., 2013). Menurut Lester et al. (2010), kalium merupakan salah satu unsur hara yang menentukan kualitas buah serta berperan besar dalam pemasaran buah, kesukaan konsumen dan juga penting dalam hubungannya dengan kesehatan manusia melalui phytonutrient. Bahkan, studi yang dilakukan oleh Demiral dan Köseoglu (2005) pada tanaman melon di rumah kaca menunjukkan bahwa pemberian $\mathrm{K}$ tambahan pada dosis yang lebih tinggi dapat meningkatkan kualitas buah melon tanpa mengurangi hasil panen yang didapatkan. Selain kalium, unsur hara lain yang turut menentukan kualitas buah adalah kalsium dan magnesium. Pemberian dolomit $150 \mathrm{~kg} \cdot \mathrm{ha}^{-1}$ diketahui dapat meningkatkan ketersediaan $\mathrm{Ca}$ dan $\mathrm{Mg}$ di dalam tanah yang berperan dalam meningkatkan kadar gula dan serat buah melon (Siswanto, 2010).

Namun demikian, faktor tanaman, tanah, dan lingkungan dapat membatasi penyerapan kalium dari dalam tanah. Untuk mengatasi kendala ini, pemberian kalium dapat dilakukan melalui daun. Jifon dan Lester (2011) menyatakan bahwa pemberian $\mathrm{K}$ melalui daun mampu meningkakan konsentrasi $\mathrm{K}$ pada jaringan tanaman, meningkatkan padatan terlarut dari sekitar $8{ }^{\circ}$ Brix menjadi $11.2{ }^{\circ}$ Brix, meningkatkan total gula, serta komponen bioaktif (asam askorbat dan beta karoten).

Selain itu, untuk mendukung pertumbuhan dan produksi tanaman buah melon, pemberian bahan organik umum dilakukan. Pemberian bahan organik 10-15 t.ha-1 dan pupuk kalium 50-150 $\quad \mathrm{K}_{2} \mathrm{O} \quad \mathrm{kg} \cdot \mathrm{ha}^{-1}$ diketahui dapat meningkatkan pertumbuhan dan produksi buah melon Amanta F1 (Safuan dan Bahrun, 2012). Namun, bahan organik memiliki pengaruh yang beragam terhadap tanaman melon, bergantung pada jenis dan sumber bahan organik yang digunakan. Menurut Risnawati (2014), pupuk kandang ayam diketahui berpengaruh sangat nyata terhadap produksi tanaman melon dibandingkan pupuk kandang sapi maupun kompos. Selain itu, media organik yang terdiri atas campuran bokashi, cocopeat, dan arang sekam sebesar 60:20:20 diketahui dapat meningkatkan kemanisan buah melon varietas Action 434 F1 (Bariyyah et al., 2015).

Tujuan penelitian ini adalah untuk mengetahui varietas melon yang memiliki produksi tinggi serta paket pemupukan yang dapat meningkatkan kualitas produksi.

\section{BAHAN DAN METODE}

Penelitian dilakukan pada musim kemarau dari bulan April 2016 sampai Juni 2016. Lokasi penelitian terletak di lahan pasir 
kuarsa di Kabupaten Kotawaringin Timur, Provinsi Kalimantan Tengah.

Rancangan penelitian yang digunakan adalah Rancangan Petak Terbagi (RPT) dengan petak utama adalah varietas melon yang terdiri atas enam varietas, dan anak petak adalah perlakuan pemupukan sebanyak enam paket pemupukan. Setiap kombinasi perlakuan diulang sebanyak tiga kali (RPT $6 \times 4 \times 3$ ). Perlakuan petak utama varietas melon yaitu: V1 = Rio F1 produksi PT Prabu Agro Mandiri. $\mathrm{V} 2$ = Action 434 F1 produksi PT BISI International Tbk.

V3 = Madesta F1 produksi PT East West Seed Indonesia.

V4 = Dewo F1 produksi PT Prabu Agro Mandiri.

V5 = Gracia F1 produksi PT East West Seed Indonesia.

V6 = Okasa F1 produksi PT Benih Citra Asia . Perlakuan anak petak adalah paket pemupukan susulan ke tiga atau fase produktif pada umur tanaman 30, 35, 40, 45, dan 50 HST. Perlakuan paket pemupukan yang digunakan adalah sebagai berikut:

$\mathrm{P} 0=$ Kontrol (tanpa $\mathrm{KCl}+$ tanpa Dolomit).

$\mathrm{P} 1=0.25 \mathrm{~kg} \mathrm{KCl}+0.1 \mathrm{~kg}$ Dolomit.

$\mathrm{P} 2=0.50 \mathrm{~kg} \mathrm{KCl}+0.2 \mathrm{~kg}$ Dolomit.

$\mathrm{P} 3=0.75 \mathrm{~kg} \mathrm{KCl}+0.3 \mathrm{~kg}$ Dolomit.

Setiap paket pemupukan susulan tersebut diencerkan ke dalam 201 air, sedangkan jumlah aplikasi setiap tanaman sebanyak $200 \mathrm{ml}$. Pemberian dolomit diharapkan dapat meningkatkan kandungan $\mathrm{Ca}$ dan $\mathrm{Mg}$ tanah sehingga mampu berpengaruh terhadap peningkatan kemanisan buah.

Setiap petak perlakuan berukuran lebar 1 $\mathrm{m}$, panjang $25 \mathrm{~m}$, dan jarak antar lubang tanaman $0.8 \mathrm{~m}$, sehingga terdapat sekitar tiga puluh tanaman per petak. Tanaman contoh setiap petak sebanyak lima tanaman. Sistem tanam dilakukan double row dengan jarak antar petak ganda adalah $0.8 \mathrm{~m}$ dan lebar antar petak ganda $3 \mathrm{~m}$. Jarak antar petak ganda satu dengan petak ganda yang berikutnya digunakan untuk penjalaran dua cabang tanaman melon, sedangkan satu cabang tanaman melon dirambatkan pada turus tegak yang difungsikan untuk cabang produksi.

Pemupukan yang dilakukan terdiri atas pupuk dasar, pupuk susulan pertama (cair), pupuk susulan kedua (padat), serta pupuk susulan ketiga (cair) sebagai perlakuan anak petak. Pemupukan tersebut sebagai berikut:
1. Pupuk dasar diaplikasikan seminggu sebelum tanam, dengan rincian: NPK $15: 15: 15+\mathrm{ZA}+\mathrm{KCl}(1: 1: 1)=20 \mathrm{~kg}$, pupuk kandang sapi $120 \mathrm{~kg}$, dan dolomit $30 \mathrm{~kg}$, untuk seratus tanaman.

2. Pupuk susulan pertama (cair) diberikan pada umur 7, 12, 17, 22, 27 HST yang terdiri atas 201 air + 0.5 kg NPK 16:16:16 untuk seratus tanaman.

3. Pupuk susulan kedua (padat) diberikan pada umur 20 HST yang terdiri atas NPK 15:15:15 + ZA + KCl (1:1:1) sebanyak satu sendok untuk setiap tanaman.

Penanaman melon menggunakan mulsa plastik hitam perak. Hal ini bertujuan untuk mengendalikan gulma, mengurangi penguapan air, mengurangi kehilangan pupuk, dan mengendalikan OPT (Organisme Pengganggu Tanaman).

Sistem perambatan dilakukan pada jarak terlebar, baik di sisi kiri maupun kanan yang saling berhadapan, dengan disertai tindakan pemangkasan. Pemangkasan cabang dilakukan pada seluruh cabang sekunder dengan disisakan tiga cabang. Dari tiga cabang yang tersisa, dua cabang dirambatkan di atas permukaan tanah dan tidak dibuahkan, sedangkan satu cabang yang lain dirambatkan ke atas menempel pada turus dan dibuahkan (cabang produksi). Setelah cabang sekunder yang berjumlah tiga tersebut mulai tumbuh memanjang, cabang tersier yang tumbuh kemudian dibuang hingga ruas daun ketujuh, dan berikutnya pada ruas 8-10 pada cabang produksi bakal buah diseleksi untuk pembesaran.

Pengendalian OPT dilakukan secara konvensional, yaitu manual dan penyemprotan dengan pestisida. Pengendalian manual dilakukan dengan mencabut gulma yang tumbuh, sedangkan pengendalian hama dan penyakit dilakukan dengan menggunakan pestisida jika telah melampaui ambang batas.

\section{HASIL DAN PEMBAHASAN}

\section{Karakteristik Tanah}

Tanah di lokasi penelitian memiliki pH yang tergolong rendah dan tampaknya bukanlah tanah yang subur secara kimia. Bahkan, berdasarkan sifat fisiknya, tanah ini juga dapat dikatakan tidak subur karena memiliki tekstur pasir (Tabel 1). 
Tabel 1. Karakteristik tanah di lokasi penelitian

\begin{tabular}{lrc}
\hline Karakteristik Tanah & Nilai & Kriteria Kesuburan \\
\hline $\mathrm{pH} \mathrm{H} \mathrm{H}_{2}(1: 2.5)$ & 4.80 & rendah \\
$\mathrm{pH} \mathrm{KCl}(1: 2.5)$ & 4.05 & - \\
$\mathrm{N}-T o t a l(\%)$ & 0.25 & sedang \\
C-organik $(\%)$ & 2.67 & sedang \\
P-Total $(\mathrm{ppm})$ & 1499.73 & sangat rendah \\
$\mathrm{K}-T o t a l(\mathrm{ppm})$ & 26.18 & sangat rendah \\
$\mathrm{K}-\mathrm{dd}\left(\mathrm{me} 100 \mathrm{~g}^{-1}\right)$ & 0.17 & rendah \\
$\mathrm{Ca}-\mathrm{dd}\left(\mathrm{me} 100 \mathrm{~g} \mathrm{~g}^{-1}\right)$ & 0.37 & sangat rendah \\
$\mathrm{Mg}-\mathrm{dd}\left(\mathrm{me} 100 \mathrm{~g}^{-1}\right)$ & 0.21 & sangat rendah \\
$\mathrm{Na}-\mathrm{dd}\left(\mathrm{me} 100 \mathrm{~g}^{-1}\right)$ & 0.04 & sangat rendah \\
$\mathrm{KB}(\%)$ & 3.62 & sangat rendah \\
$\mathrm{KTK}\left(\mathrm{me} 100 \mathrm{~g}^{-1}\right)$ & 21.84 & sedang \\
$\mathrm{Al}-\mathrm{dd}\left(\mathrm{me} 100 \mathrm{~g}^{-1}\right)$ & 0.30 & - \\
$\mathrm{H}-\mathrm{dd}\left(\mathrm{me} 100 \mathrm{~g}^{-1}\right)$ & 0.12 & - \\
$\mathrm{Kejenuhan} \mathrm{Al}(\%)$ & 23.71 & tinggi \\
Pasir $(\%)$ & 90.60 & - \\
Debu $(\%)$ & 3.59 & - \\
Liat $(\%)$ & 6.81 & - \\
\hline
\end{tabular}

Meskipun bertekstur pasir, tanah tersebut telah lama diusahakan sebagai lahan pertanian sayuran dengan penggunaan pupuk kandang sapi yang intensif. Oleh karena itu, kandungan bahan organik tanah tergolong sedang. Adapun karakteristik tanah yang lain memiliki kriteria sangat rendah hingga sedang. Hal ini dapat disebabkan pada tanah yang bertekstur pasir unsur hara yang ditambahkan mudah hilang tercuci. Sebaliknya kandungan aluminium yang cukup tinggi berpotensi dapat mengakibatkan keracunan pada perakaran tanaman.

\section{Perlakuan Varietas Melon}

Berdasarkan peubah pertumbuhan yaitu panjang tanaman dan jumlah daun, V2 (Action
434 F1) paling baik dan berbeda nyata dengan varietas lainnya. Perlakuan varietas V1 (Rio F1) dan V4 (Dewo F1) termasuk paling rendah (Tabel 2).

Produksi bobot buah terbaik adalah pada perlakuan varietas V3 (Madesta F1) dan berbeda nyata dengan varietas lainnya, kecuali dengan V2 (Action F1). Perlakuan varietas V1 (Rio F1) tergolong memiliki bobot buah terendah. Diameter buah dan panjang buah tampaknya memiliki pola yang mirip dengan bobot buah, hanya pada diameter buah yang paling rendah adalah V6 (Okasa F1). Hal tersebut menunjukkan pewarisan genetik memegang peranan penting pada peubah komponen hasil (Shamioul dan Askar, 2011).

Tabel 2. Peubah pertumbuhan dan hasil enam varietas melon di tanah pasir kuarsa musim kemarau

\begin{tabular}{lccccc}
\hline Varietas & $\begin{array}{c}\text { Panjang } \\
\text { Tanaman } \\
(\mathrm{cm})\end{array}$ & $\begin{array}{c}\text { Jumlah } \\
\text { Daun } \\
\text { (helai) }\end{array}$ & $\begin{array}{c}\text { Bobot } \\
\text { Buah } \\
(\mathrm{kg})\end{array}$ & $\begin{array}{c}\text { Diameter } \\
\text { Buah } \\
(\mathrm{cm})\end{array}$ & $\begin{array}{c}\text { Panjang } \\
\text { Buah } \\
(\mathrm{cm})\end{array}$ \\
\hline Rio F1 & $139.10 \mathrm{a}$ & $22.03 \mathrm{a}$ & $2.76 \mathrm{a}$ & $14.80 \mathrm{ab}$ & $14.82 \mathrm{a}$ \\
Action 434 F1 & $214.90 \mathrm{~d}$ & $30.72 \mathrm{~d}$ & $3.41 \mathrm{de}$ & $16.10 \mathrm{~d}$ & $16.73 \mathrm{~d}$ \\
Madesta F1 & $159.50 \mathrm{~b}$ & $25.79 \mathrm{~b}$ & $3.68 \mathrm{e}$ & $16.10 \mathrm{~d}$ & $16.78 \mathrm{~d}$ \\
Dewo F1 & $140.00 \mathrm{a}$ & $21.82 \mathrm{a}$ & $3.29 \mathrm{c}$ & $15.20 \mathrm{c}$ & $15.48 \mathrm{~b}$ \\
Gracia F1 & $187.30 \mathrm{c}$ & $28.33 \mathrm{c}$ & $3.34 \mathrm{~cd}$ & $14.90 \mathrm{bc}$ & $16.23 \mathrm{c}$ \\
Okasa F1 & $171.60 \mathrm{bc}$ & $24.48 \mathrm{~b}$ & $2.89 \mathrm{~b}$ & $14.40 \mathrm{a}$ & $16.28 \mathrm{c}$ \\
\hline
\end{tabular}

Keterangan: Huruf yang sama pada kolom yang sama tidak berbeda nyata pada uji DMRT taraf 5\%. 
Rasa melon umumnya tersimpan pada daging buah, bahkan kandungan air yang terdapat pada rongga buah juga memiliki rasa manis. Meskipun air di dalam rongga buah tidak dikonsumsi secara langsung, air rongga tersebut dapat dimanfaatkan dalam pembuatan minuman segar atau jus melon.

Air rongga melon ternyata lebih manis dibandingkan daging buah melon yang posisinya mendekati kulit melon. Kemanisan air rongga paling tinggi terdapat pada perlakuan varietas V1 (Rio F1) dan V4 (Dewo F1), sedangkan yang terendah terdapat pada perlakuan varietas V5 (Gracia F1) (Tabel 3).

Posisi daging buah melon menunjukkan tingkat kemanisan yang berbeda. Kemanisan dekat rongga jauh lebih tinggi (7.85-12.66 ${ }^{\circ}$ Brix) dibandingkan kemanisan dekat dengan kulit buah (5.35-8.55 ${ }^{\circ}$ Brix). Hal tersebut sejalan dengan penelitian Ahmed (2009) bahwa tingkat kemanisan daging melon mendekati rongga lebih tinggi dibandingkan mendekati kulit. Varietas yang tertinggi tingkat kemanisannya adalah perlakuan varietas V6 (Okasa F1) dan V1 (Rio F1). Sedangkan kemanisan daging buah melon total tertinggi diperoleh pada perlakuan varietas V1 (Rio F1) sebesar $11.79{ }^{\circ}$ Brix dan berbeda nyata dibandingkan varietas lainnya, sedangkan yang terendah adalah perlakuan varietas V2 (Action F1) sebesar $6.60{ }^{\circ}$ Brix.

Penelitian ini menunjukkan bahwa perlakuan varietas V2 (Action $434 \mathrm{~F} 1$ ) memiliki kemanisan terendah. Hasil yang serupa juga didapat di Bogor, tingkat kemanisan varietas Action 434 F1 hanya mencapai $5.8{ }^{\circ}$ Brix (Khumaero et al., 2014). Sebaliknya pada penelitian di Malang, varietas Action 434 F1 menghasilkan tingkat kemanisan cukup tinggi mencapai $10.55^{\circ}$ Brix (Ginting et al., 2015).
Melon mulai dipanen pada umur 61 HST dengan tujuan agar kualitas melon tetap baik dan tidak mudah rusak sehingga dapat dijual dengan cepat. Namun demikian, pada umur panen yang sama, tidak semua varietas mencapai matang fisiologis sesuai yang diharapkan. Hal tersebut menyebabkan tingkat kemanisan melon relatif rendah. Pada umur 61 HST varietas Action 434 F1, Gracia F1 dan Dewo F1 masih belum matang optimal, sedangkan varieta Rio F1, Madesta F1 dan Okasa F1 sudah mencapai matang optimal.

Grumet et al. (2007) menyatakan bahwa tingkat kematangan dapat dideteksi dari banyaknya gas etylen yang dihasilkan. Gas ini mencerminkan terkumpulnya sukrosa yang merupakan komponen utama penyebab rasa manis dan terkumpulnya karoten di dalam daging buah melon. Selain itu, tingkat kematangan juga dapat dipengaruhi oleh periode setelah antesis pada melon. Semakin bertambah panjang periode setelah antesis pada melon, dari 12 hingga 35 hari setelah antesis, maka kadar gula total, persentase Soluble Solid Total, serta vitamin C akan semakin meningkat (Beauliea dan Lea, 2007). Sejalan dengan hal tersebut, studi yang dilakukan Ghanbarian et al. (2007) menunjukkan bahwa dari empat tahapan yaitu 12, 24, 36, dan 48 hari setelah pembentukan bunga, tingkat kemanisan buah melon varietas Semsouri semakin meningkat, berturut-turut 4.5, 5.1, 5.7, dan $7.1^{\circ}$ Brix.

Perbedaan peubah pengamatan antar varietas melon lebih mengarah kepada faktor genetik varietas yang diuji. Aragao et al. (2013) mengemukakan bahwa dari 38 aksesi melon yang dibudidayakan petani Brazilia ditemukan keragaman genetik yang luas sehingga memiliki keragaman termasuk diameter buah, bobot basah, dan tingkat kemanisan buah.

Tabel 3. Kualitas enam varietas melon di tanah pasir kuarsa di musim kemarau

\begin{tabular}{lccccc}
\hline Varietas & $\begin{array}{c}\text { Kemanisan } \\
\text { Air } \\
\text { Rongga } \\
\left({ }^{\circ} \text { Brix }\right)\end{array}$ & $\begin{array}{c}\text { Kemanisan } \\
\text { Daging dekat } \\
\text { Rongga } \\
\left({ }^{\circ} \text { Brix }\right)\end{array}$ & $\begin{array}{c}\text { Kemanisan } \\
\text { Daging Dekat } \\
\text { Kulit } \\
\left({ }^{\circ} \text { Brix }\right)\end{array}$ & $\begin{array}{c}\text { Kemanisan } \\
\text { Daging } \\
\text { Total } \\
\left({ }^{\circ} \text { Brix }\right)\end{array}$ & $\begin{array}{c}\text { Jumlah } \\
\text { Biji }\end{array}$ \\
\hline Rio F1 & $12.13 \mathrm{e}$ & $15.50 \mathrm{f}$ & $8.08 \mathrm{e}$ & $11.79 \mathrm{f}$ & $322 \mathrm{~b}$ \\
Action 434 F1 & $8.23 \mathrm{~b}$ & $7.85 \mathrm{a}$ & $5.35 \mathrm{a}$ & $6.60 \mathrm{a}$ & $334 \mathrm{c}$ \\
Madesta F1 & $9.40 \mathrm{c}$ & $10.13 \mathrm{c}$ & $7.55 \mathrm{~d}$ & $8.84 \mathrm{c}$ & $401 \mathrm{~d}$ \\
Dewo F1 & $12.05 \mathrm{e}$ & $12.66 \mathrm{e}$ & $6.65 \mathrm{c}$ & $9.65 \mathrm{~d}$ & $286 \mathrm{a}$ \\
Gracia F1 & $7.58 \mathrm{a}$ & $9.00 \mathrm{~b}$ & $5.88 \mathrm{~b}$ & $7.44 \mathrm{~b}$ & $403 \mathrm{~d}$ \\
Okasa F1 & $10.28 \mathrm{~d}$ & $11.80 \mathrm{~d}$ & $8.55 \mathrm{f}$ & $10.18 \mathrm{e}$ & $397 \mathrm{~d}$ \\
\hline
\end{tabular}

Keterangan: Huruf yang sama pada kolom yang sama tidak berbeda nyata pada uji DMRT taraf 5\%. 
Kualitas buah melon yang didasarkan pada tingkat kemanisannya diukur dengan $\%$ sukrosa atau ${ }^{\circ}$ Brix. Menurut International Ag Labs Inc., terdapat empat kelas kualitas melon yang didasarkan pada tingkat kemanisan, yaitu: buruk $8{ }^{\circ}$ Brix, sedang $12{ }^{\circ}$ Brix, baik $14{ }^{\circ}$ Brix dan sangat baik $16{ }^{\circ}$ Brix. Kualitas melon varietas Rio F1 dan Okasa F1 tergolong sedang, sedangkan varietas lainnya tergolong buruk.

Pada peubah jumlah biji, tampak bahwa jumlah biji terbanyak terdapat pada tiga varietas melon, yaitu: Gracia F1, Madesta F1, dan Okasa F1. Sebaliknya yang paling rendah adalah Dewo F1 yang hanya memiliki 286 biji.

\section{Perlakuan Paket Pemupukan}

Paket pemupukan fase produktif berpengaruh nyata terhadap peubah pertumbuhan, hasil, maupun mutu. Tampak bahwa paling tidak terdapat satu perlakuan yang berbeda nyata dengan perlakuan lainnya (Tabel 4 dan Tabel 5).

Perlakuan paket pemupukan terbaik yaitu P2 untuk peubah panjang tanaman, jumlah daun, dan bobot buah. Aplikasi kalium melalui pupuk $\mathrm{KCl}$ ternyata menunjukkan hasil terbaik pada perlakuan P2 namun akan menurun pada peubah yang diamati pada perlakuan pemupukan lebih tinggi. Penelitian yang dilakukan Olaniyi dan Tella (2011) menunjukkan bahwa pertumbuhan melon masih meningkat dengan pemupukan $\mathrm{K}_{2} \mathrm{O}$ sebesar $40 \mathrm{kgha}^{-1}$, sedangkan hasil panen tertinggi dengan pemupukan $\mathrm{K}_{2} \mathrm{O} 30 \mathrm{kgha}^{-1}$, diatas dosis tersebut cenderung terjadi penurunan peubah. Sedangkan peningkatan pemberian dolomit memberikan peningkatan bobot buah maksimal pada perlakuan P2, pada pemupukan lebih tinggi mengalami penurunan. Hal ini sesuai dengan penelitian Sari et al. (2013) yang menunjukkan bahwa setiap peningkatan pemberian $\mathrm{Ca}$ akan meningkatkan bobot tanaman melon. Kemanisan total pada paket P2 mampu mencapai $9.46{ }^{\circ}$ Brix dan berbeda nyata dibandingkan kontrol $(8.62$ ${ }^{\circ}$ Brix). Tingginya tingkat kemanisan total perlakuan P2 disebabkan meningkatnya serapan unsur $\mathrm{K}, \mathrm{Ca}$, dan $\mathrm{Mg}$ oleh tanaman yang dapat meningkatkan kadar gula pada buah melon. Menurut Siswanto (2010), pemberian bahan organik 20 tha $^{-1}+$ kalium $175 \mathrm{kgha}^{-1}+$ dolomit $150 \mathrm{kgha}^{-1}$ meningkatkan kadar gula melon sebesar $13.44 \%$.

Tabel 4. Pengaruh paket pemupukan terhadap peubah pertumbuhan dan hasil melon di tanah pasir kuarsa pada musim kemarau

\begin{tabular}{cccccc}
\hline Perlakuan & $\begin{array}{c}\text { Panjang } \\
\text { Tanaman } \\
(\mathrm{cm})\end{array}$ & $\begin{array}{c}\text { Jumlah } \\
\text { Daun } \\
\text { (helai) }\end{array}$ & $\begin{array}{c}\text { Bobot } \\
\text { Buah } \\
(\mathrm{kg})\end{array}$ & $\begin{array}{c}\text { Diameter } \\
\text { Buah } \\
(\mathrm{cm})\end{array}$ & $\begin{array}{c}\text { Panjang } \\
\text { Buah } \\
(\mathrm{cm})\end{array}$ \\
\hline P0 & $162.20 \mathrm{a}$ & $26.49 \mathrm{~b}$ & $3.34 \mathrm{c}$ & $16.18 \mathrm{~b}$ & $16.59 \mathrm{~b}$ \\
P1 & $155.30 \mathrm{a}$ & $23.78 \mathrm{a}$ & $2.84 \mathrm{a}$ & $14.85 \mathrm{a}$ & $15.81 \mathrm{a}$ \\
P2 & $185.90 \mathrm{~b}$ & $26.92 \mathrm{~b}$ & $3.61 \mathrm{~d}$ & $14.98 \mathrm{a}$ & $15.90 \mathrm{a}$ \\
P3 & $164.60 \mathrm{a}$ & $24.93 \mathrm{ab}$ & $3.11 \mathrm{~b}$ & $14.95 \mathrm{a}$ & $15.92 \mathrm{a}$ \\
\hline
\end{tabular}

Keterangan: Huruf yang sama pada kolom yang sama tidak berbeda nyata pada uji DMRT taraf 5\%.

Tabel 5. Peubah kualitas melon berdasarkan paket pemupukan di tanah pasir kuarsa di musim kemarau

\begin{tabular}{lccccc}
\hline Perlakuan & $\begin{array}{c}\text { Kemanisan } \\
\text { Air } \\
\text { Rongga } \\
\left({ }^{\circ} \text { Brix }\right)\end{array}$ & $\begin{array}{c}\text { Kemanisan } \\
\text { Daging Dekat } \\
\text { Rongga } \\
\left({ }^{\circ} \text { Brix }\right)\end{array}$ & $\begin{array}{c}\text { Kemanisan } \\
\text { Daging Dekat } \\
\text { Kulit } \\
\left({ }^{\circ} \text { Brix }\right)\end{array}$ & $\begin{array}{c}\text { Kemanisan } \\
\text { Daging } \\
\text { Total } \\
\left({ }^{\circ} \text { Brix }\right)\end{array}$ & $\begin{array}{c}\text { Jumlah } \\
\text { Biji }\end{array}$ \\
\hline P0 & $9.02 \mathrm{a}$ & $9.88 \mathrm{a}$ & $7.35 \mathrm{c}$ & $8.62 \mathrm{a}$ & $376 \mathrm{c}$ \\
P1 & $10.18 \mathrm{c}$ & $11.22 \mathrm{~b}$ & $6.88 \mathrm{~b}$ & $9.05 \mathrm{~b}$ & $343 \mathrm{~b}$ \\
P2 & $9.58 \mathrm{~b}$ & $11.26 \mathrm{c}$ & $7.37 \mathrm{c}$ & $9.46 \mathrm{c}$ & $378 \mathrm{c}$ \\
P3 & $10.98 \mathrm{~d}$ & $11.97 \mathrm{c}$ & $6.43 \mathrm{a}$ & $9.20 \mathrm{~b}$ & $331 \mathrm{a}$ \\
\hline
\end{tabular}

Keterangan: Huruf yang sama pada kolom yang sama tidak berbeda nyata pada uji DMRT taraf 5\%. 
Kemanisan melon tampaknya juga berhubungan dengan banyaknya jumlah daun. Jumlah daun yang banyak dapat meningkatkan luasan daun dan tingkat asimilasi sehingga mampu meningkatkan kemanisan buah melon. Wira et al. (2011) nengungkapkan bahwa tingginya indeks luas daun total mampu meningkatkan TSS buah melon.

\section{Interaksi Varietas Melon dan Paket Pemupukan}

Interaksi nyata terjadi antara varietas melon dengan paket pemupukan terhadap peubah hasil maupun mutu. Setiap varietas menunjukkan respon yang berbeda pada setiap perlakuan paket pemupukan (Tabel 6, Tabel 7, dan Tabel 8). Kombinasi perlakuan yang menghasilkan bobot buah tertinggi adalah pada varietas Madesta FI yang disertai paket pemupukan P3. Tampak bahwa Madesta F1 adalah satu-satunya varietas yang menunjukkan respon positif dengan meningkatnya dosis $\mathrm{KCl}$ dan dolomit yang ditambahkan. Pada dosis pemupukan tertinggi, Madesta F1 mampu menghasilkan bobot buah tertinggi dibandingkan varietas yang lain, yaitu sebesar $4.55 \mathrm{~kg}$ (Tabel 7). Namun, dari segi mutu buah (kemanisan total), Madesta F1 tidak menunjukkan kecenderungan yang positif sejalan dengan peningkatan dosis pemupukan. Satu-satunya varietas yang menunjukkan respon positif sejalan dengan peningkatan dosis pemupukan hingga dosis pemupukan tertinggi adalah Okasa F1. Tingkat kemanisan pada varietas ini cenderung meningkat hingga tingkat kemanisan tertinggi dicapai pada perlakuan P3 sebesar $12.05{ }^{\circ}$ Brix. Walaupun demikian, nilai ini bukanlah yang tertinggi di antara yang lain. Nilai kemanisan tertinggi sebesar $13.05^{\circ}$ Brix diperoleh pada varietas Rio F1 yang disertai perlakuan pemupukan P2. Varietas Rio F1 cenderung menunjukkan respon yang positif terhadap peningkatan dosis pemupukan namun hanya sampai pada dosis sedang (P2), selanjutnya pada dosis yang lebih tinggi menunjukkan penurunan tingkat kemanisan menjadi $11.15^{\circ}$ Brix (Tabel 7).

Satu hal yang menjadi perhatian adalah adanya korelasi negatif namun tidak terlalu erat antara bobot buah dengan tingkat kemanisan total $(r=-0.31 ; p=0.007)$, yang berarti bahwa bobot buah cenderung berbanding terbalik dengan tingkat kemanisan total. Sebagai contoh adalah varietas Madesta F1, dengan adanya peningkatan dosis pemupukan, bobot buah semakin meningkat tetapi tingkat kemanisan total cenderung mengalami penurunan (Tabel 7).

Tabel 6. Interaksi paket pemupukan terhadap pertumbuhan melon di tanah pasir kuarsa pada musim kemarau.

\begin{tabular}{|c|c|c|c|c|c|c|c|c|}
\hline \multirow{2}{*}{ Perlakuan } & \multicolumn{4}{|c|}{ Panjang Tanaman } & \multicolumn{4}{|c|}{ Jumlah Daun } \\
\hline & P0 & P1 & P2 & P3 & $\mathrm{P} 0$ & P1 & $\mathrm{P} 2$ & P3 \\
\hline \multirow{2}{*}{ V1 } & $157.60 \mathrm{~b}$ & $124.40 \mathrm{c}$ & $157.13 \mathrm{~b}$ & $117.27 \mathrm{a}$ & $3.25 \mathrm{~d}$ & $2.57 \mathrm{~b}$ & $3.11 \mathrm{c}$ & $2.09 \mathrm{a}$ \\
\hline & B & B & A & A & B & A & A & B \\
\hline \multirow{2}{*}{ V2 } & $216.20 \mathrm{~b}$ & $181.47 \mathrm{a}$ & $224.93 \mathrm{c}$ & $237.07 \mathrm{~d}$ & $3.57 \mathrm{~b}$ & $3.21 \mathrm{a}$ & $3.21 \mathrm{a}$ & $3.63 \mathrm{~b}$ \\
\hline & $\mathrm{D}$ & A & E & $\mathrm{E}$ & $\mathrm{D}$ & $\mathrm{D}$ & $\mathrm{AB}$ & E \\
\hline V3 & $\begin{array}{c}175.60 \mathrm{~b} \\
\mathrm{C}\end{array}$ & $\begin{array}{c}154.00 \mathrm{a} \\
\mathrm{C}\end{array}$ & $\begin{array}{c}176.07 \mathrm{~b} \\
\mathrm{BC}\end{array}$ & $\begin{array}{c}132.20 \mathrm{c} \\
\mathrm{B}\end{array}$ & $\begin{array}{c}2.73 \mathrm{a} \\
\mathrm{A}\end{array}$ & $\begin{array}{c}3.23 \mathrm{~b} \\
\mathrm{E}\end{array}$ & $\begin{array}{c}4.19 \mathrm{c} \\
\mathrm{E}\end{array}$ & $\begin{array}{c}4.55 \mathrm{~d} \\
F\end{array}$ \\
\hline V4 & $112.07 \mathrm{a}$ & $119.73 \mathrm{~b}$ & $173.00 \mathrm{c}$ & $\underset{r}{155.27 \mathrm{~d}}$ & $\begin{array}{c}4.01 \mathrm{c} \\
\mathrm{F}\end{array}$ & $2.62 \mathrm{~b}$ & $\begin{array}{c}4.01 \mathrm{c} \\
\mathrm{D}\end{array}$ & $\begin{array}{c}2.50 \mathrm{a} \\
\mathrm{B}\end{array}$ \\
\hline \multirow{2}{*}{ V5 } & $112.07 \mathrm{a}$ & $168.60 \mathrm{~b}$ & $194.00 \mathrm{c}$ & $191.60 \mathrm{c}$ & $4.01 \mathrm{~d}$ & $2.68 \mathrm{a}$ & $3.94 \mathrm{c}$ & $3.25 \mathrm{~b}$ \\
\hline & A & D & $\mathrm{D}$ & D & E & A & $\mathrm{C}$ & D \\
\hline V6 & $\begin{array}{c}187.20 \mathrm{~b} \\
\mathrm{D}\end{array}$ & $\begin{array}{c}183.40 \mathrm{~b} \\
\mathrm{E}\end{array}$ & $\begin{array}{c}182.53 \mathrm{~b} \\
\mathrm{C}\end{array}$ & $\begin{array}{c}154.13 \mathrm{a} \\
\mathrm{C}\end{array}$ & $\begin{array}{c}3.50 \mathrm{~d} \\
\mathrm{C}\end{array}$ & $\begin{array}{c}2.73 \mathrm{~b} \\
\mathrm{C}\end{array}$ & $\begin{array}{c}3.22 \mathrm{c} \\
\text { B }\end{array}$ & $\begin{array}{c}2.65 \mathrm{a} \\
\mathrm{C}\end{array}$ \\
\hline
\end{tabular}

Keterangan: Huruf besar yang sama pada kolom yang sama dan huruf kecil yang sama pada baris yang sama tidak berbeda nyata pada uji DMRT taraf $5 \%$. 
Tabel 7. Interaksi paket pemupukan terhadap peubah produksi (bobot buah) dan mutu melon (kemanisan total) di tanah pasir kuarsa pada musim kemarau

\begin{tabular}{|c|c|c|c|c|c|c|c|c|}
\hline \multirow{2}{*}{ Perlakuan } & \multicolumn{4}{|c|}{ Bobot Buah } & \multicolumn{4}{|c|}{ Kemanisan Total } \\
\hline & P0 & P1 & P2 & P3 & P0 & P1 & P2 & P3 \\
\hline \multirow[t]{2}{*}{ V1 } & $3.25 \mathrm{~d}$ & $2.57 \mathrm{~b}$ & $3.11 \mathrm{c}$ & $2.09 \mathrm{a}$ & $10.50 \mathrm{a}$ & $12.45 \mathrm{c}$ & $13.05 \mathrm{~d}$ & $11.15 \mathrm{~b}$ \\
\hline & B & A & A & A & $\mathrm{D}$ & F & E & E \\
\hline \multirow[t]{2}{*}{ V2 } & $3.57 \mathrm{~b}$ & $3.21 \mathrm{a}$ & $3.21 \mathrm{a}$ & $3.63 \mathrm{~b}$ & $5.55 \mathrm{a}$ & $7.50 \mathrm{~d}$ & $7.05 \mathrm{c}$ & $6.30 \mathrm{~b}$ \\
\hline & $\mathrm{D}$ & $\mathrm{C}$ & B & E & A & B & A & A \\
\hline \multirow[t]{2}{*}{ V3 } & $2.73 \mathrm{a}$ & $3.23 \mathrm{~b}$ & $4.19 \mathrm{~b}$ & $4.55 \mathrm{c}$ & $9.25 \mathrm{c}$ & $8.60 \mathrm{a}$ & $8.65 \mathrm{a}$ & $8.85 \mathrm{~b}$ \\
\hline & A & $\mathrm{C}$ & $\mathrm{E}$ & $\mathrm{F}$ & $\mathrm{C}$ & $\mathrm{C}$ & B & $\mathrm{C}$ \\
\hline \multirow[t]{2}{*}{ V4 } & $4.01 \mathrm{c}$ & $2.62 \mathrm{~b}$ & $4.01 \mathrm{c}$ & $2.50 \mathrm{a}$ & $10.55 \mathrm{~d}$ & $9.65 \mathrm{c}$ & $9.12 \mathrm{a}$ & $9.30 \mathrm{~b}$ \\
\hline & E & $\mathrm{AB}$ & $\mathrm{D}$ & B & D & E & $\mathrm{C}$ & $\mathrm{D}$ \\
\hline \multirow[t]{2}{*}{ V5 } & $4.01 \mathrm{c}$ & $2.68 \mathrm{a}$ & $3.94 \mathrm{c}$ & $3.25 \mathrm{~b}$ & $10.55 \mathrm{~d}$ & $7.00 \mathrm{a}$ & $7.15 \mathrm{~b}$ & $7.55 \mathrm{c}$ \\
\hline & $\mathrm{E}$ & B & $\mathrm{C}$ & $\mathrm{D}$ & D & A & A & B \\
\hline \multirow[t]{2}{*}{ V6 } & $3.50 \mathrm{c}$ & $2.73 \mathrm{a}$ & $3.22 \mathrm{~b}$ & $2.65 \mathrm{a}$ & $8.05 \mathrm{a}$ & $9.10 \mathrm{~b}$ & $11.75 \mathrm{c}$ & $12.05 \mathrm{~d}$ \\
\hline & $\mathrm{C}$ & $\mathrm{BC}$ & B & $\mathrm{C}$ & B & D & D & $\mathrm{F}$ \\
\hline
\end{tabular}

Keterangan: Huruf besar yang sama pada kolom yang sama dan huruf kecil yang sama pada baris yang sama tidak berbeda nyata pada uji DMRT taraf $5 \%$.

Hal ini dapat disebabkan bobot buah yang tinggi cenderung lebih banyak mengandung air yang berakibat pada menurunnya tingkat kemanisan buah. Suhandy et al. (2015) bobot buah melon yang lebih tinggi diperoleh perlakuan kebutuhan air dicukupi $100 \%$, dibandingkan perlakuan kecukupan kebutuhan air hanya $60 \%$. Namun tingkat kemanisan buah melon terjadi kebalikannya, dimana buah yang memiliki bobot lebih tinggi akibat kecukupan air 100\% lebih rendah yaitu $8.97{ }^{\circ}$ Brix dibandingkan bobot buah yang lebih rendah akibat kecukupan air hanya $60 \%$ yaitu sebesar $10.98{ }^{\circ}$ Brix.
Pemberian kalium dan dolomit mampu meningkatkan kadar gula dalam buah dan serat buah melon (Siswanto et al., 2010). Menurut Sidik et al. (2013), salah satu yang mempengaruhi nilai maksimum kadar gula Total Soluble Solid (TSS) adalah varietas. Tingginya nilai TSS juga menunjukkan tingginya kandungan asam askorbat atau vitamin $\mathrm{C}$ yang terkandung di dalam melon. Hal tersebut juga merupakan penentu kualitas buah melon. Melo et al. (2013) menyatakan bahwa melon mengakumulasi unsur hara $\mathrm{N}, \mathrm{Ca}, \mathrm{K}, \mathrm{P}$, $\mathrm{Mg}, \mathrm{S}, \mathrm{B}, \mathrm{Fe}, \mathrm{Mn}, \mathrm{Zn}, \mathrm{Cu}$, sedangkan yang mempengaruhi tingkat kemanisan besar dugaan adalah N, Ca dan K.

Tabel 8. Interaksi pengaruh perlakuan paket pemupukan terhadap peubah mutu melon di tanah pasir kuarsa pada musim kemarau

\begin{tabular}{|c|c|c|c|c|c|c|c|c|}
\hline \multirow{2}{*}{ Perlakuan } & \multicolumn{4}{|c|}{ Kemanisan Dekat Kulit } & \multicolumn{4}{|c|}{ Kemanisan Dekat Rongga } \\
\hline & P0 & P1 & P2 & P3 & P0 & P1 & P2 & P3 \\
\hline \multirow[t]{2}{*}{ V1 } & $8.00 \mathrm{~b}$ & $7.90 \mathrm{~b}$ & $10.00 \mathrm{c}$ & $6.40 \mathrm{a}$ & $13.00 \mathrm{a}$ & $17.00 \mathrm{~d}$ & $16.10 \mathrm{c}$ & $15.90 \mathrm{~b}$ \\
\hline & $\mathrm{C}$ & D & D & $\mathrm{C}$ & D & $\mathrm{F}$ & E & F \\
\hline \multirow[t]{2}{*}{ V2 } & $5.00 \mathrm{a}$ & $6.00 \mathrm{c}$ & $5.20 \mathrm{~b}$ & $5.20 \mathrm{~b}$ & $6.10 \mathrm{a}$ & $9.00 \mathrm{c}$ & $8.90 \mathrm{c}$ & $7.40 \mathrm{a}$ \\
\hline & A & A & A & A & A & B & A & A \\
\hline \multirow[t]{2}{*}{ V3 } & $8.50 \mathrm{c}$ & $7.20 \mathrm{a}$ & $7.10 \mathrm{a}$ & $7.40 \mathrm{~b}$ & $10.00 \mathrm{a}$ & $10.00 \mathrm{a}$ & $10.20 \mathrm{~b}$ & $10.30 \mathrm{~b}$ \\
\hline & $\mathrm{D}$ & $\mathrm{C}$ & $\mathrm{C}$ & $\mathrm{D}$ & $\mathrm{C}$ & C & B & $\mathrm{C}$ \\
\hline \multirow[t]{2}{*}{ V4 } & $8.10 \mathrm{~d}$ & $7.00 \mathrm{c}$ & $6.10 \mathrm{~b}$ & $5.40 \mathrm{a}$ & $13.00 \mathrm{~b}$ & $12.30 \mathrm{a}$ & $12.13 \mathrm{a}$ & $13.20 \mathrm{c}$ \\
\hline & $\mathrm{C}$ & B & B & B & D & D & $\mathrm{C}$ & D \\
\hline \multirow[t]{2}{*}{ V5 } & $8.10 \mathrm{~d}$ & $6.00 \mathrm{c}$ & $5.30 \mathrm{~b}$ & $5.10 \mathrm{a}$ & $13.00 \mathrm{~d}$ & $8.00 \mathrm{a}$ & $9.00 \mathrm{~b}$ & $10.00 \mathrm{c}$ \\
\hline & $\mathrm{C}$ & A & A & A & D & A & A & B \\
\hline \multirow[t]{2}{*}{ V6 } & $7.10 \mathrm{a}$ & $7.20 \mathrm{a}$ & $10.50 \mathrm{c}$ & $9.10 \mathrm{~b}$ & $9.00 \mathrm{a}$ & $11.00 \mathrm{~b}$ & $13.00 \mathrm{c}$ & $15.00 \mathrm{~d}$ \\
\hline & B & $\mathrm{C}$ & $\mathrm{E}$ & E & B & $\mathrm{E}$ & D & $\mathrm{E}$ \\
\hline
\end{tabular}

Keterangan: Huruf besar yang sama pada kolom yang sama dan huruf kecil yang sama pada baris yang sama tidak berbeda nyata pada uji DMRT taraf $5 \%$. 


\section{KESIMPULAN}

Perlakuan varietas melon dan paket pemupukan fase produktif memiliki pengaruh nyata pada peubah yang diamati, baik peubah pertumbuhan, produksi, maupun mutu. Terkait dengan peubah produksi, varietas Madesta F1 memiliki keunggulan dalam hal bobot buah, diameter buah, dan panjang buah. Sedangkan terkait dengan mutu, varietas Rio F1 paling unggul dalam tingkat kemanisan buah. Paket pemupukan sedang (P2) menunjukkan performa terbaik, baik dalam hal peubah pertumbuhan, produksi, maupun mutu buah. Terdapat interaksi yang nyata antara varietas dan dosis pemupukan fase produktif terhadap peubah produksi maupun mutu. Madesta F1 adalah satu-satunya varietas yang menunjukkan respon positif dengan meningkatnya dosis $\mathrm{KCl}$ dan dolomit yang ditambahkan dengan bobot buah tertinggi sebesar $4.55 \mathrm{~kg}$ dicapai pada perlakuan dosis tinggi (P3). Sebaliknya, varietas Rio F1 menunjukan respon positif dengan adanya peningkatan dosis hingga dosis sedang $(\mathrm{P} 2)$ dengan nilai kemanisan tertinggi di antara yang lain sebesar $13.05{ }^{\circ}$ Brix, namun menurun pada dosis tinggi (P3). Sebaliknya, Bobot buah berkorelasi negatif yang tidak terlau erat dengan tingkat kemanisan total buah, semakin tinggi bobot cenderung menurunkan tingkat kemanisan buah.

\section{DAFTAR PUSTAKA}

Ahmed, O.K. 2009. Evaluation of objective maturity indices for muskmelon (Cucumis melo) cv. "Galia". Journal of King Abdulaziz University - Science. 21(2): 317-326.

Aragao, F.A.S., J.T. Filho, G.H.S. Nunes, M.A. Queiroz, P.N. Bordallo, G.S.C. Buso, M.A. Ferreira, Z.P. Costa, F.B. Neto. 2013. Genetic divergence among accession of melon from traditional agriculture of Brazilian Northeast. J. Genet. and Mol. Res. 12(4): 6356-6371.

Asao, T., M. Asaduzzaman, M.F. Mondal, M. Tokura, F.Adachi, M. Ueno, T. Ban. 2013. Impact of reduced potassium nitrate concentrations in nutrient solution on the growth, yield and fruit quality of melon in hydroponics. Scientia Horticulturae. 164: 221-231.

Bariyyah, K., S. Suparjono, Usmadi. 2015. Pengaruh kombinasi media organik dan konsentrasi nutrisi terhadap daya hasil tanaman melon (Cucumis melo L.). Planta Tropika. J. Agro Sains. 3(2): 67-72.

Beauliea, J.C., J.M. Lea. 2007. Quality changes in cantaloupe during growth, maturation, and in store fresh-cut cubes prepared from fruit harvested at various maturities. J. Amer. Soc. Hort. Sci. 132(5): 720-728.

Bouzo, C.A., S.B. Cortez. 2012. Effect of calcium foliar application on the fruit quality of melon. J. Revista RIA-INTA. 38(3): 1-6.

Demiral, M.A., A.T. Köseoglu. 2005. Effect of potassium on yield, fruit quality, and chemical composition of greenhousegrown Galia melon. Journal of Plant Nutrition. 28(1): 93-100.

Gadomaka, J.M. 2009. Mineral content of melon fruit (Cucumis melo L.). J. Elementol. 14(4): 717-727.

Ghanbarian, F., Z.A. Shojaei, A. Ebrahimi, S. Yuneji. 2007. Physical properties and composional change of two cultivar of cantalaoupe fruit during various maturity stages. J. Agri. Res. 25(2): 117-125.

Ginting, R.R., Sitawati, Y.B.S. Heddy. 2015. Efikasi zat pengatur tumbuh etefon untuk mempercepat pemasakan buah melon (Cucumis melo L.). J. Prod. Tan. 3(3): 189-194.

Grumet, R., N.L. Katzir, H.A. Little, V. Portnoy, Y. Burger. 2007. New insights into reproductive development in melon (Cucumis melo L.). J. Intl. of Plant Dev. Biol. 1(2): 253-264.

International AG LABS. 2017. Reflactive index of crop juices, calibtated in \% sukrose or ${ }^{\circ}$ Brix. www.aglabs.com. [4 Oktober 2017]. 
Jifon, J.L., G.E. Lester. 2011. Effect of foliar potassium fertilizer and source on cantaloupe yield and quality. J. Better Crop. 95(1): 13-15.

Khumaero, W.W., D. Efendi, W.B. Suwarno, Sobir. 2014. Evaluasi karakteristik hortikultura empat genotipe melon (Cucumis melo L.). J. Hort. Indonesia. 5(1): 56-63.

Lester, G.E., J.L. Jifon, D.J. Makus. 2010. Impact of potassium nutrition on postharvest fruit quality: Melon (Cucumis melo L) case study. Plant and Soil. 335(1): 117-131.

Melo, D.M., H.M.O. Charlo, R. Castoldi, R.F. Gomes, L.T. Braz. 2013. Nutrient accumulation in "Fantasy" net melon cultivated on substrate. J. Siencias Agrarias, Londrina. 34(4): 1673-1682.

Milind, P., S. Kulwant. 2011. Musk melon is eat-must melon. J. Intl. Res. of Pharmacy. 2(8): 52-57.

Olaniyi, J.O., B.A. Tella. 2011. Effect of nitrogen and potassium fertilizer on the growth, seed yield and nutritional value of egusi melon (Citrulus lanatus (thumb) manf.) in Ogbosomo South West Nigeria. Int. Res. J. of Plant Sci. 2(11): 328-331.

Risnawati. 2014. Pengaruh pemakaian bahan organik terhadap produksi tanaman melon. J. Agrium. 18(3): 269-271.

Safuan, L.O., A. Bahrun. 2012. Pengaruh bahan organik dan pupuk kalium terhadap pertumbuhan dan produksi tanaman melon (Cucumis melo L.). J. Agroteknos. 2(2): 69-76.

Sari, D.P., Y.C. Ginting, D. Pangaribuan. 2013. Pengaruh konsentrasi kalsium terhadap pertumbuhan dan produksi dua varietas tanaman melon (Cucumis melo L.) pada sistem hidroponik media padat. J. Agrotropika. 18(1): 29-33.
Setyawaty, R. Wijaya. 2012. Respon pertumbuhan dan produksi tanaman melon (Cucumis melo L.) terhadap kombinasi biodegradable super absorbent polymer dengan pupuk majemuk NPK di tanah miskin hara. J. Agrium. 17(3): 155-162.

Shamioul, G.M., E.H. Askar. 2011. Genetic behaviour of yield quality traits in sweet melon Esmalawi variety (Cucumis meloVar Agyptiacus). J. Plant prod. 2(12): 1731-1739.

Sidik, N.J., S. Hashim, Y.S. Mohd., S. Abdullah. 2012. Characterization of plant growth, yield and fruit quality of rockmelon (Cucumis melo) cultivars planted on soilless culture. J. of Plant Sciences. 7(5): 186-193.

Simanungkalit, P., J. Ginting, T. Simanungkalit. 2013. Respon pertumbuhan dan produksi tanaman melon (Cucumis melo L.) terhadap pemberian pupuk NPK dan pemangkasan buah. J. Agroekotek. 1(2): 238-248.

Siswanto. 2010. Meningkatkan Kadar Gula Buah Melon. UPN. Veteran Jawa Timur.

Siswanto, B. Wisnu, Purwadi. 2010. Karakteristik lahan untuk tanaman melon (Cucumis melo L) dalam kaitannya dengan peningkatan kadar gula. J. Pert. Mapeta. 12(2): 72-144.

Suhandy, D., A. Tusi, I. Novianti, M. Yulia. 2015. Analisis hubungan target pemberian air irigasi terhadap nilai leaf water potensial dan kandungan padatan terlarut pada tanaman melon (Cucumis melo L.). Prosiding Seminar Nasional Sains dan Teknologi, Lembaga Penelitian dan Pengabdian Kepada Masyarakat. Universitas Lampung, Bandar Lampung, 3 November 2015. Hal: 398-408.

Wira, A.B., I.M. Razi, Z.A. Jamil. 2011. Compost as additives in coconut coir dust for growing rockmelon (Cucumis melo L.). J. Trop. Asgric. and Fd. Sci. 39(2): 229-237. 